\title{
Relationship between Psychological Contract Violation, Supervisory Support, Psychological Contract Breach and Organizational Citizenship Behavior
}

\author{
Sibgha Sadiq \\ Foundation University Islamabad
}

\begin{abstract}
The purpose of the study is to examine the relationship between psychological contract breach and organizational citizenship behavior with the mediating role of psychological contract violation and supervisory support is acting as moderator. We are presenting here five hypotheses simultaneously, which we have based on theoretical relations effects of all the four variables.( Psychological Contract Violation, Supervisory Support, Psychological Contract Breach and Organizational Citizenship Behavior). The data was collected from a sample of 250 employees of Pakistan National Council of the Arts and Planning and development commission of Pakistan. Convenient sampling method was used to obtain fair results. We used Correlation/Regressions analysis so that we can explore the mediating effects of Psychological Contract Violation on the relationships between psychological contract breach and organizational citizenship behaviors. In order to analyze the moderation, a stepwise hierarchical regression method was used, this method moderate variable and moderates the relationship that exists between Psychological Contract Breach and Organizational Citizenship Behavior. A negative relationship was found between psychological contract breach and organizational citizenship behavior which was mediated by Psychological Contract Violation. such that the relationship was stronger for the employees with low Psychological Contract Violation.

This study puts forward PCV as a strong reliant factor is mediating the relationship of $P C B$ and $O C B$ and supervisory support as strengthening factor that moderates the relationship of $P C V$ and OCB, Our research will help the managers to understand the role of psychological contract violation (PCV) and supervisory support (SS) at the work place and how to use it positively for productivity of the organization,..
\end{abstract}

Keywords: Psychological contract breach, employees, Psychological Contract Violation , OCB, Organization/Workplace.

\subsection{Background}

\section{Introduction}

In the past, many researchers have been conducted on employee's reaction to psychological contract violation. From past 15 years, extraordinary growth has been observed in the research of psychological contract (Csoka, 1995; Deery et al., 2006). The psychological contract can be described as the belief or perceptions which an employee might have about the terms and conditions of agreement based on mutual exchange between that particular individual or employee and the organization which have employed him. (Schein, 1965, Rousseau, 1989;). It may be stated that the psychological contract includes those promises and terms which have been made between the employee and the organization which have employed him, and it settles on what both parties can give to each other (Rousseau, 1995. Whereas, when an organization is unable and finds it difficult to fulfill those promises and obligations which are being perceived by employee then it is called as psychological contract breach (PCB), (Rousseau, 1989). This attribute which is being described as psychological contract breach has a negative relation with much type of workplace behaviors and attitudes. e.g commitment, job satisfaction, and organizational citizenship behaviors (Robinson and Morrison, 1995; Turnley and Feldman, 2000). The other state of PCB is that state which is negatively affected by the observation or perception of $\mathrm{PCB}$, this state is called psychological contract violation (PCV).

For very first time Organizational citizenship behavior (OCB) was defined and explained by Organ (1988) as to supportive behavior of individuals that are outside of normal job requirements and that are not rewarded. The investigation in OCB attempts to discover in citizenship behaviors what and how employees are engaged and thereby raising organizational productivity. The relationship of OCB and PCV has been studied with another factor supervisor support (SS) (Cho \& Johanson, 2008; Wayne, 1997).

\subsection{Knowledge Gap}

According to M. Suazo (2008), the psychological contract breach could be examined with such workplace outcomes as trust, cynicism, turnover and a variety of OCBs (e.g. interpersonal helping, voice, altruism). Therefore, a clear knowledge gap exists in this field of study. 


\subsection{Problem Statement}

In our study we are examining the mediating role of psychological contract violation in the relationship of psychological contract breach and organizational citizenship behavior.. Further the study focuses to investigate the moderating role of supervisory support.

\subsection{Significance of the study}

In the recent years psychological contract and organizational citizenship behavior has drawn the attention of the researchers both in practical and theoretical circles However, it has not been establish as to what is the role of psychological contract as a mediator on the relationship of psychological contract breach and organizational citizenship behavior (M. Suazo, 2008). The study would help the managers to understand the role of psychological contract violation (PCV) and supervisory support (SS) at the work place and how to use it positively for productivity of the organization. This study puts forward PCV as a strong reliant factor is mediating the relationship of $\mathrm{PCB}$ and $\mathrm{OCB}$ and supervisory support as strengthening factor that moderates the relationship of PCV and OCB.

\subsection{Objective}

Following are the objectives of the study:

- To examine the effect of psychological contract breach on organizational citizenship behavior.

- To examine the relationship which exists between PCB and PCV.

- To explore the relationship between PCV and OCB.

- To explore effect of psychological contract violation as a mediator on the relationship of PCB and OCB.

- To find the impact of supervisory support as a mediator on the relationship of PCV and OCB.

\subsection{The Relationship between PCB and OCB}

\section{Literature Review}

The area of OCB research is considered as it is related to psychological contract. PCB is considered as a forebear or predictor to OCB. The practical findings which are being highlighted on the basis of these studies put forward the idea or view that PCB is negatively related to the OCBs (e.g. Robinson, 1996; Robinson and Morrison, 1995; Turnley et al., 2003; Turnley and Feldman, 2000). For example, Robinson (1996) studied PCB as a forbearer to OCB and explained that a negative relationship exists between PCB and performance of civic virtue behaviors.

The above mentioned researches show that PCB is negative antecedent of OCB. so based on the past literature, following hypothesis can be generated.

H1: $P C B$ negatively influences $O C B$

\subsection{The Relationship between PCB and PCV}

In the early stages of work in this field, Psychological Contract Breach and Psychological Contract Violation were often used in place of each other. (Suazo, Turnley \& Mai, 2005). As distinguished by Morrison and Robinson (1997), Psychological Contract Breach and Psychological Contract Violation are different concepts. Perception of an individual that he is not being rewarded as he was promised, is the concept of Psychological Contract breach and violation is defined as the action taken due to contract breach that may be in the form of disturbance and annoyance (Raja et al, 2004). The higher the breach size higher would be the violation size, so these two are positively related to each other (Morrison \& Robinson, 1997; Raja et al, 2004). According to Robinson and Morrison (2000) greater the feeling of perceived breach the greater the size of violation.

The above mentioned researches show that PCB is positively related to OCB. so based on the past literature, following hypothesis can be generated.

$H$ 2: $P C B$ positively influence $P C V$

\subsection{The Relationship between PCV and OCB}

According to Specter and Fox (2002) emotion act as a adaptive function and there is a negative relation between organizational citizenship behavior and psychological contract violation. To engage in OCB the willingness is reduced, due to negative emotional response and while willingness is increased due positive emotional response (Rousseau ,1989). According to another theory a good citizen behavior can be accomplished when an employee feel respected, otherwise feeling of betrayal leads to an effected employee behavior (Rousseau ,1989). According to Robinson and Morrison (1995) employees, feeling of violation of contract by the organization resulted in decreased contributions to the organization by employees.

The above mentioned researches show that PCV is negative antecedent of OCB. so based on the past literature, following hypothesis can be generated. 
H3: PCV positively influence OCB.

\subsection{The PCV as a Mediator}

It is important to note that PCB leads to PCV (Morrison and Robinson, 1997). Many researchers have shown that it is not necessary that every event of PCB is followed by an emotional reaction which is attached with PCV (Morrison and Robinson, 1997; Turnley and Feldman, 1999). For example, it was contented by Morrison and Robinson (1997) that the degree and the extent of the unfulfilled promise play a very important role in the rise of PCB to PCV. Therefore, PCV is instrument by which we may interpret PCB into negative workplace behaviors (Suazo et al., 2005). Particularly; PCV is seen as a key mediating variable why has negative relation with work place attitudes. And OCB is being important among them.

The above mentioned researches show that PCV acts as a mediator in the relationship of PCB and OCB, so based on the past literature, following hypothesis can be generated

H4: $P C V$ mediates the relationship of $P C B$ and $O C B$

\subsection{The Supervisory Support as a moderator}

Many researchers have shown that greater supervisor support increase employees demonstration of OCB (Podsakoff et al. 2000), It means that people having higher supervisory support display more OCB under some limited conditions. Empirical findings have shown that supervisory support helps in motivating employees OCB. On the other hand researchers examined that the psychological contract changes due to socialization, support of supervisor and new comers psychological contracts (De Vos, Buyens and Schalk, 2003). Therefore, we can say that supervisory support changes the relationship between PCV and OCB.

The above mentioned researches show that supervisory support is a moderating variable on the relationship of PCV and OCB. So based on the past literature, following hypothesis can be generated.

H5: supervisory support moderates the relationship of $P C V$ and $O C B$

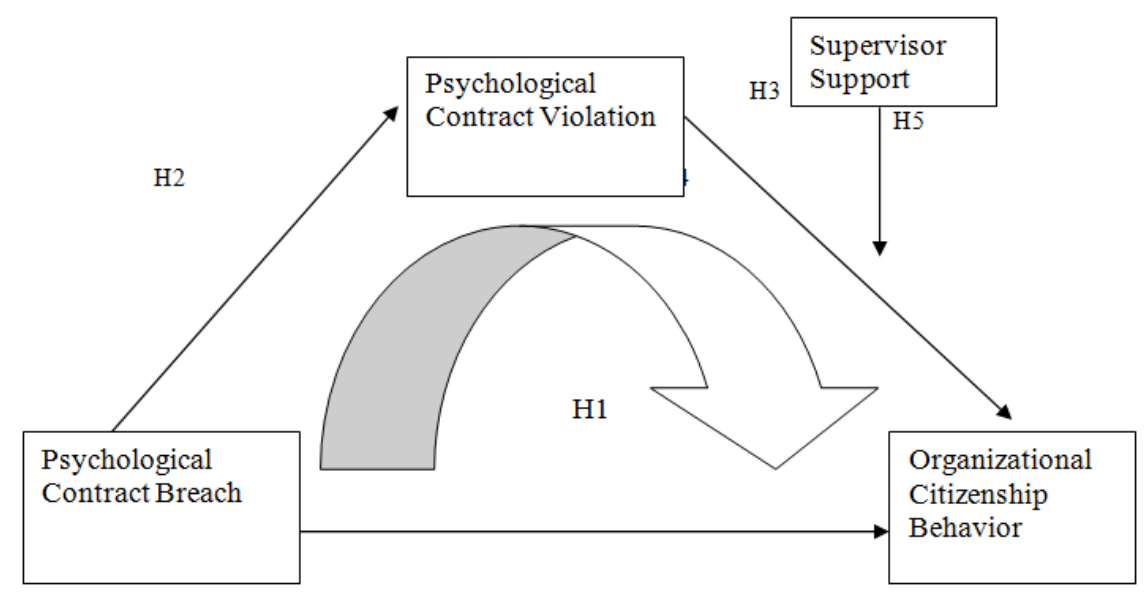

\subsection{Design of the study}

\section{Research Methodology}

This is a quantitative research. The study design of this research is causal and cross-sectional in nature. Public servants employees of various ministries are the participant of this research. The organizations included in study were Pakistan National Council of the Arts and Planning and development commission of Pakistan. Staff of these organizations comes under the tandem of Ministry of Finance, Ministry of Heritage and Integration .We used convenient sampling to collect the response of all the participants. It was collected from that population which was easily accessible to us. The sample size of the research was 250 . PCB and PCV were measured by using Robinson and Morrison (2000) scale. Using likert scale anchored by (1) strongly disagrees and (5) strongly agree. We measured OCB by using Podsakoff et al.'s (1990) Organizational Citizenship Behavior Questionnaire (OCBQ) it consist of five factors which were highlighted by Organ (1988): altruism , courtesy, civic virtue, sportsmanship and Conscientiousness. Supervisory support was measured by Greenhaus, and Parasuraman's (1990) scale.

\subsection{Reliability for the Instrument}

SPSS version 16 was used to analyze the data. The Alpha Reliability value for the PCB, PCV, OCB, and SS was measured as above 0.7 showing the strong internal consistency for the tool. 
Table1 Reliability of four variables

\begin{tabular}{ccc}
\hline Variable & Cronbach Alpha & No of items \\
PCB & .86 & 6 \\
PCV & .86 & 4 \\
OCB & .87 & 6 \\
Supervisor Support & .85 & 6 \\
\hline
\end{tabular}

\section{Analyses And Discussion}

\subsection{Hypothesis testing}

Testing of hypothesis was done through linear regression analysis.

Table 2: Regression analysis of three variables.

Coefficients $^{\mathrm{a}}$

\begin{tabular}{|c|c|c|c|c|c|c|}
\hline & \multirow[b]{2}{*}{ Variable } & \multicolumn{2}{|c|}{ Unstandardized Coefficients } & \multirow{2}{*}{$\frac{\begin{array}{c}\text { Standardized } \\
\text { Coefficients }\end{array}}{\text { Beta }}$} & \multirow[b]{2}{*}{$\mathrm{t}$} & \multirow[b]{2}{*}{ Sig. } \\
\hline & & B & Std. Error & & & \\
\hline 1. & $\operatorname{Pcb}(* 1)$ & -.294 & .075 & -.307 & -3.929 & .000 \\
\hline 2. & $\operatorname{Pcb}(* 2)$ & .553 & .061 & .597 & 9.052 & .000 \\
\hline 3. & $\operatorname{Pcv}(* 1)$ & -.609 & .068 & -.590 & -8.895 & .000 \\
\hline
\end{tabular}

Table 2 shows the relationships between three variables under study. The model 1 in the table shows relationship between $\mathrm{PCB}$ and OCB. The t-value and sig .000 evidence that there exists negative influence of PCB on OCB. Robinson (1996) studied PCB as an predecessor to OCB and explained that there exist negative relationship between PCB and performance of civic virtue behaviors. It means that if employee's perceived promises are not fulfilled then the employee will show negative civic virtue. Therefore, hypothesis 1 is accepted

Model 2 shows the relationship between PCB and PCV. The t-value and sig .000 evidence that positive influence of $\mathrm{PCB}$ on PCV. It means What a person thinks that he has not been rewarded as was promised to him is the concept of Psychological Contract breach and violation is defined as the action taken due to contract breach that may be in the form of annoyance and dissatisfaction (Raja et al, 2004). Therefore, hypothesis 2 is accepted.

Model 3 shows the relationship between PCV and OCB. The t-value and sig .000 evident a negative influence of PCV on OCB. Morrison (1995) employees, feeling of violation of contract by the organization resulted in decreased contributions to the organization by employees. Therefore, hypothesis 3 is accepted.

Table 3: Model summary of mediation

\begin{tabular}{|c|c|c|c|c|}
\hline \multicolumn{5}{|c|}{ Model Summary } \\
\hline Model & $\mathrm{R}$ & R Square & Adjusted R Square & $\begin{array}{l}\text { Std. Error of the } \\
\text { Estimate }\end{array}$ \\
\hline 1 & $.307^{\mathrm{a}}$ & .094 & .088 & .80846 \\
\hline 2 & $.600^{\mathrm{b}}$ & .359 & .351 & .68225 \\
\hline
\end{tabular}

Table 4: Coefficient table of mediation Coefficients $^{\mathbf{a}}$

\begin{tabular}{|c|c|c|c|c|c|c|}
\hline \multirow{2}{*}{\multicolumn{2}{|c|}{ Model }} & \multicolumn{2}{|c|}{ Unstandardized Coefficients } & \multirow{2}{*}{$\begin{array}{c}\begin{array}{c}\text { Standardized } \\
\text { Coefficients }\end{array} \\
\text { Beta }\end{array}$} & \multirow[b]{2}{*}{$\mathrm{t}$} & \multirow[b]{2}{*}{ Sig. } \\
\hline & & B & Std. Error & & & \\
\hline \multirow[t]{2}{*}{1} & (Constant) & 2.381 & .260 & & 9.154 & .000 \\
\hline & Mpcb & .294 & .075 & .307 & 3.929 & .000 \\
\hline \multirow[t]{3}{*}{$\overline{2}$} & (Constant) & 1.457 & .249 & & 5.842 & .000 \\
\hline & Mpcb & -.066 & .078 & -.069 & -.844 & .400 \\
\hline & $\mathrm{Mpcv}$ & .591 & .076 & .638 & 7.799 & .000 \\
\hline
\end{tabular}




\begin{tabular}{|c|c|c|c|c|c|c|}
\hline \multicolumn{7}{|c|}{ Coefficients $^{\mathrm{a}}$} \\
\hline \multirow{2}{*}{\multicolumn{2}{|c|}{ Model }} & \multicolumn{2}{|c|}{ Unstandardized Coefficients } & \multirow{2}{*}{$\begin{array}{c}\begin{array}{c}\text { Standardized } \\
\text { Coefficients }\end{array} \\
\text { Beta }\end{array}$} & \multirow[b]{2}{*}{$\mathrm{t}$} & \multirow[b]{2}{*}{ Sig. } \\
\hline & & B & Std. Error & & & \\
\hline \multirow[t]{2}{*}{1} & (Constant) & 2.381 & .260 & & 9.154 & .000 \\
\hline & Mpcb & .294 & .075 & .307 & 3.929 & .000 \\
\hline \multirow[t]{3}{*}{2} & (Constant) & 1.457 & .249 & & 5.842 & .000 \\
\hline & Mpcb & -.066 & .078 & -.069 & -.844 & .400 \\
\hline & $\mathrm{Mpcv}$ & .591 & .076 & .638 & 7.799 & .000 \\
\hline
\end{tabular}

a. Dependent Variable: Mocb

We measured results of mediation by making use of Barron and Kenny's mediation model. However three pre-requisite were satisfied before running mediation. Three of them were significant.

Table 4 shows the mediating effect of PCV. The increased value of $\mathrm{R}=.600$ shows that the relationship between PCB and OCB is being mediated by PCV. The insignificant value of PCB and significant value of OCB shows that there exists full mediation. It means that PCV takes the impact from PCB and transfers it to OCB.

In order to analyze the moderation, a stepwise hierarchical regression method was given by Baron and Kenny (1986), this method moderate variable and moderates the relationship that exists between independent and dependent variable

Table 5: Model summary of Moderation

Model Summary

\begin{tabular}{lcccc}
\hline \hline Model & $\mathrm{R}$ & $\mathrm{R}$ Square & Adjusted R Square & $\begin{array}{c}\text { Std. Error of the } \\
\text { Estimate }\end{array}$ \\
\hline 1 & $.597^{\mathrm{a}}$ & .356 & .352 & .80496820 \\
2 & $.597^{\mathrm{b}}$ & .356 & .348 & .80766620 \\
\hline \hline
\end{tabular}

a. Predictors: (Constant), Zscore(Mpcv)

b. Predictors: (Constant), Zscore(Mpcv), modvar

Table 6: Coefficients table of Moderation Coefficients $^{\mathrm{a}}$

\begin{tabular}{|c|c|c|c|c|c|c|}
\hline \multirow{2}{*}{\multicolumn{2}{|c|}{ Model }} & \multicolumn{2}{|c|}{ Unstandardized Coefficients } & \multirow{2}{*}{$\begin{array}{c}\begin{array}{c}\text { Standardized } \\
\text { Coefficients }\end{array} \\
\text { Beta }\end{array}$} & \multirow[b]{2}{*}{$\mathrm{t}$} & \multirow[b]{2}{*}{ Sig. } \\
\hline & & B & Std. Error & & & \\
\hline \multirow[t]{2}{*}{1} & (Constant) & $-2.530 \mathrm{E}-15$ & .066 & & .000 & 1.000 \\
\hline & Zscore(Mpcv) & .597 & .066 & .597 & 9.052 & .000 \\
\hline \multirow[t]{3}{*}{2} & (Constant) & .003 & .073 & & .048 & .962 \\
\hline & Zscore(Mpcv) & .595 & .068 & .595 & 8.702 & .000 \\
\hline & modvar & -.008 & .074 & -.008 & -.113 & .910 \\
\hline
\end{tabular}

$\overline{\text { a. Dependent Variable: Zscore(Mocb) }}$

Table 6 shows the moderation effect of supervisor support. The value of $\mathrm{R}$ remained constant and the value of product term is $\mathrm{p}<.05$ that shows that supervisor support does not moderates the relationship between PCV and OCB.

\section{Conclusions}

Following conclusions are drawn from the study:

- There exists negative relationship between OCB and PCB. It means that if perceived obligations and promises are not fulfilled by the employer than the employee will show negative discretionary behavior towards the organization.

- There exists negative relationship between PCV and OCB. It means It means that to engage in OCB the willingness is reduced, due to negative emotional response and while willingness is increased due positive emotional response

- The relationship of PCB and OCB is being mediated by psychological contract breach . PCV is instrument through which PCB may be interpreted into negative workplace behaviors

- $\quad$ Supervisory support does not moderate the relationship of PCV and OCB. 
Following are the recommendations of the study:

\section{Recommendations}

- Future research may be conducted to investigate trait based or cognitive based mediating variables, for example work ethics may have an effect on an employee's reaction to PCB

- Research may be carried out to examine more moderating variables which might have an effect on relation between OCB and PCB.

\section{References:}

[1]. Rousseau, D.M. (1989), "Psychological and implied contracts in organizations", Employee Responsibilities and Rights Journal, Vol. 2, pp. 121-39.

[2]. Morrison, E.W. and Robinson, S.L. (1997), "When employees feel betrayed: a model of how psychological contract violation develops", Academy of Management Review, Vol. 22, pp. 226-56.

[3]. Robinson, S.L. and Morrison, E.W. (2000), "The development of psychological contract breach and violation: a longitudinal study", Journal of Organizational Behavior, Vol. 21, pp. 525-46.

[4]. Schein, E.H. (1965), Organizational Psychology, Prentice-Hall, Englewood Cliffs, NJ.

[5]. Organ, D.W. (1988). OCB: The good soldier syndrome. Lexington, MA: Lexington Books.

[6]. Cho, S., \& Guchait, G. (2009). Psychological Contracts and Perceived Organizational Support in India: Investigating the Impact on Intent to Leave. The International Council on Hotel, Restaurant and Institutional Education, San Francisco, CA.

[7]. Wayne, S., Shore, L., \& Liden, R. (1997). Perceived organizational support and leader-member exchange: A social exchange perspective. Academy of Management Journal, 40, 82-111.

[8]. Kram, K.E. Mentoring at Work: Developmental Relationships in Organizational Life. Glenview, IL: Scott, Foresman, 1985

[9]. Turnley, W.H. and Feldman, D.C. (1999a), "The impact of psychological contract violations on exit, voice, loyalty, and neglect", Human Relations, Vol. 52, pp. 895-922.

[10]. Turnley, W.H. and Feldman, D.C. (1999b), "A discrepancy model of psychological contract violations", Human Resource Management Review, Vol. 9, pp. 367-86.

[11]. Suazo, M.M., Turnley, W.H. and Mai-Dalton, R.R. (2005), "The role of perceived violation in determining employees' reactions to psychological contract breach", Journal of Leadership \& Organizational Studies, Vol. 12, pp. 24-36.

[12]. Podsakoff, P. M., MacKenzie, S. B., Paine, J. B., \& Bachrach, D. G. (2000). Organizational citizenship behaviors: A critical review of theoretical and empirical literature and suggestions for future research. Journal of Management, 26, 513-563. Podsakoff, P. M., Mackenzie, S. B., \& Podsakoff, N

[13]. Robinson, S.L. and Morrison, E.W. (2000), "The development of psychological contract breach and violation: a longitudinal study", Journal of Organizational Behavior, Vol. 21, pp. 525-46.

[14]. Greenhaus, J.H.; Parasuraman, S.; and Wormley, W.M. Race effects of organizational experience, job performance evaluation, and career outcomes. Academy of Management Journal, 33, 1 (1990), 64-96

[15]. Ortony, A., Clore, G., \& Collins, A. 1988. The cognitive structure of emotions. Cambridge, England: Cambridge University Press.

[16]. Schein, E. H. 1965. Organizational psychology. Englewood Cliffs, NJ: Prentice Hall.

[17]. Rousseau, D. M. 1989. Psychological and implied contracts in organizations. Employee Re-sponsibilities and Rights Journal, 2: 121139.

[18]. De Vos, A., Buyens, D., Schalk, R. 2003. Psychological contract development during organizational socialization: Adaptation to reality and the role of reciprocity. Journal of Organizational Behavior, 24: 537-559.

[19]. Raja, U., Johns, G. \& Ntalianis, F. (2004). The impact of personality on psychological contracts. Academy of Management Journal, 47, 350-367.

[20]. Robinson, S. L., \& Morrison, E. W. (2000). The development of psychological contract breach and violation: A longitudinal study. Journal of Organizational Behavior, 21: 525-546.

[21]. Morrison, E.W. \& Robinson, S.L. (1997). When employees feel betrayed: a model of how psychological contract violation develops, Academy of Management Review, 22,226-256.

[22]. Spector PE, Fox S (2002). An emotion-centered model of voluntary work behavior: Some parallel between counterproductive work behavior and organizational citizenship behavior. Hum. Resour. Manage. Rev., 12: 269-292.

[23]. Robinson SL, Morrison EW (1995). Psychological contracts and OCB: The effect of the unfulfilled obligations on civic virtue. J. Organ. Behav., 16: 289-298. 